\title{
Effects of PEG Priming and Fungicide Treatment on Kenaf (Hibiscus cannabinus L.) Seed Germination
}

\author{
In-Sok Lee, Chan-Ho Kang, Suk-Ju Kwon and Young-Eun Na \\ Jeollabuk-do Agricultural Research \& Extension Services, Iksan City 54591, Korea
}

\begin{abstract}
An experiment was conducted in the Jeollabuk-do Agricultural Research and Extension Services, Korea from February to June 2017, to study the effect of polyethylene glycol (PEG) on the germination of kenaf seeds variety 'Jangdae', which treated with seven PEG concentrations ( $0 \%, 10 \%, 20 \%, 25 \%, 30 \%, 35 \%$ and $40 \%$ ) for 24 h at $20{ }^{\circ} \mathrm{C}$ in the dark, and evaluate the effect of fungicide on surging kenaf seed germination in the field. Results showed that the critical concentration rate needed to hasten germination based on germination percentage, times to reach $50 \%$ of the final germination rate (T50) and mean no. of days to germination (MDG) is using 10\% PEG. A maximum germination rate of $83.8 \%$ using hydro-priming (HP) (seed treated with HP) was observed during the first $12 \mathrm{~h}$ of treatment. The control's (Jangdae seed) germination increased sharply and reached a maximum germination rate of $53.2 \%$ on the 21 st day in the field. After $21 \mathrm{~d}$, germination of all priming treatments ranged from $13.8 \%$ to $26.3 \%$. The palisade layer (PAL) after priming treatment was more damaged than that of the control. Also, a significant difference on the acid level between the control and PEG priming treatment $(p<0.05)$ was observed. It was also found out that seed modifications after priming could affect in the field. A fungicide called “Tiram” was used after priming to help kenaf seeds decrease T50 and MDG, and increase germination percentage. Results showed that application of fungicide after priming optimizes seed germination and vigor. Therefore, it is recommended to invigorate the kenaf seed before planting.
\end{abstract}

Key words: Kenaf, priming, polyethylene glycol, fungicide.

\section{Introduction}

Kenaf (Hibiscus cannabinus L.) belongs to family Malvaceae is a common warm season annual fiber plant native to India and Africa [1]. Although kenaf is a tropical plant, its cultivars are now well adapted to a wide geographical and climatic range [2]. Kenaf plants have been widely used for the production of paper, biocomposites, fiber boards, bioplasticsand in the textile industry. It is an important cordage crop in many developing countries such as USA and Japan used for fiber production and forage. Kenaf was introduced in Korea in the 60's but, limited use in the country. In recent years, its value in Korea has been increasing for forage, biomass production and fuel.

Kenaf can reach heights of 4-6 m depending on environmental conditions and requires $140-150 \mathrm{~d}$ to

Corresponding author: In-Sok Lee, Ph.D., research field: crop cultivation.

Running title: Agricultural Properties of Kenaf Seed Treated with PEG and Fungicide complete maturity. Seed production is limited to frost-free areas for the late ripening variety. Its stalk is composed of two distinct fibers, the bast and the core, which is approximately $35 \%$ and $65 \%$ of mass, respectively [3]. The bast is characterized as a bark with long fibers and the core being physically similar to balsawood, containing soft, short fibers. They lose germination capacity after harvest because of high seed oil content. Under conditioned storage of $20^{\circ} \mathrm{C}$ and $10 \%$ humidity, kenaf remained viable for about eight months [4]. However, its viability loss is faster under hot and humid climates with an average ambient temperature of $35^{\circ} \mathrm{C}$ and humidity above $60 \%$ [5]. A kenaf variety called 'Jangdae' released by the Korea Atomic Energy Research Institute (KAERI) is an early maturing variety and has low germination rate which is a major limitation for commercially use in Korea.

The rapid and uniform field emergences of seeds are the two important conditions to increase quality, yield and profit in annual crops. Slow germination 
ability of some seeds results to smaller seedlings and consequently smaller plants. This also makes such seedlings more vulnerable to soil-borne diseases [6]. A seed represents an amalgam of individuals, each with different germination vigor, but uniform performance of seeds of cultivated plants is seldom achieved [7]. Because of this, seed priming has become a common treatment to increase the rate and uniformity of emergence in many vegetable and flower species resulting to a more rapid and uniform germination when the seeds are re-imbibed [8]. Seed priming has been used to accelerate germination, uniform seedling emergence and improve germination performance under temperature or drought stresses [9, 10]. Seed osmopriming using polyethylene glycol (PEG) had improved the germination potential of some herbaceous perennials [11], pigeonpea [12], brassica [13] and carrot [14]. However, the secret to successful seed priming is ceasing the priming treatment at the right time to allow re-drying, hence each species must be investigated for optimal priming treatments and treatment durations [15].

Previous results showed that chemical agent treatments to kenaf seeds could be used to decrease seedling damage caused by pathogens [16, 17]. Fungicides evaluated by Whiteley [18] did not reduce germination of kenaf seed; but no beneficial effects were shown. Field studies by White et al. [19] indicated that seedling emergence was higher for chemically-treated kenaf seeds, while laboratory tests indicated that treatments had no effect on germination. If seeds are primed with various priming materials, the outer tissue of seeds is weakened, causing seeds to be attacked by many pathogens. So, there is a need to use fungicide to prevent the seeds from having a poor quality.

Thus, the main objective of this study was performed to investigate the effect of PEG on improving germination percentage of kenaf seeds (Jangdae), identify the cause of low priming effect and evaluate the effect of fungicide on surging kenaf seed germination.

\section{Materials and Methods}

\subsection{Seed and Other Materials Preparation}

The kenaf variety used was "Jangdae" from the KAERI. The experiment was conducted in Agri-Food Processing, Agricultural Research and Extension Services, Iksan from February to April, 2017. Seeds, weighing $12 \mathrm{~g}$ for each treatment were sterilized by soaking in $\mathrm{NaOCl}$ solution for $10 \mathrm{~min}$ and dried for 30 min. Twistpack (A) 400 (Twist pack 3, ACE Industry, Pocheon, Korea) containers were purchased at a store.

\subsection{Germination Tests to PEG in Laboratory Condition}

In the conduct of PEG (Polyethylene glycol 6000, Aldrich, Darmstadt, Germany) test, an osmopriming agent solution, seeds were treated with seven PEG concentrations $(0 \%, 10 \%, 20 \%, 25 \%, 30 \%, 35 \%$ and $40 \%$ ) for $24 \mathrm{~h}$ at $20{ }^{\circ} \mathrm{C}$ in the dark in an incubator (HB-302S-4, Hanbaek Scientific Co., Bucheon, Korea). Three replicates with 20 seeds each were placed in Twist pack (A) 400 (Twist pack 3, ACE Industry, Pocheon, Korea) container with two filter paper soaked with $7 \mathrm{~mL}$ test solutions, and germinated for $72 \mathrm{~h}$ at $25{ }^{\circ} \mathrm{C}$ with lights in the incubator. Germination was recorded at the same time daily. The seed have germinated when it was $>2 \mathrm{~mm}$ and the seed coat ruptured, plumule and radicle came out. After $3 \mathrm{~d}$ of germination, a picture was taken to compare growth phase of plants. The times to reach 50\% of the final germination rate (T50) and the mean no. of days to germination (MDG) were recorded to evaluate germination performance.

\subsection{Germination Tests to PEG in Field Condition}

Kenaf was planted on 1st May, 2017 in a deep loamy fertile soil and sown at a density of about 25,000 plants/10a. The beds were $10 \mathrm{~m}$ and $1.5 \mathrm{~m}$ wide with each bed having seven planted rows $0.2 \mathrm{~m}$ apart. The field was cleaned and treated with $3 \mathrm{~kg}$ 
pendimethalin herbicide/10a and 15-10-10 NPK granular fertilizer/10a, which was partially modified from Ref. [20], applied into the upper $10 \mathrm{~cm}$ of the soil before planting. The plots were designed by completely randomized block with three replicates. The kenaf seeds were treated with seven PEG concentrations $(0 \%, 10 \%, 20 \%, 25 \%, 30 \%, 35 \%$ and $40 \%$ ) for $24 \mathrm{~h}$ at $20{ }^{\circ} \mathrm{C}$ in the dark in an incubator (HB-302S-4, Hanbaek Scientific Co., Bucheon, Korea). The primed seeds were left for $2 \mathrm{~h}$ to allow the seed surface to dry and were then sown in the field. Germination was scored for $21 \mathrm{~d}$. A seed has germinated when the leaves come out. Biomass yield was measured at $160 \mathrm{~d}$ after sowing using a two digit balance and expressed in ton/10a.

\subsection{Scanning Electron Microscope (SEM) Image}

The seeds were air-dried for $48 \mathrm{~h}$ at $30{ }^{\circ} \mathrm{C}$. Each was then fastened using a nipper before cutting vertically to avoid mechanical injury for the vertical section filming. The specimen were air-dried for $20 \mathrm{~h}$ at $80{ }^{\circ} \mathrm{C}$ to shoot, then was placed on aluminum stub and plated with gold by using a gold ion sputtering device (Jeol, JFC-1100E, Fine Coat, Tokyo, Japan) at $10 \mathrm{~mA}$ for $400 \mathrm{~s}$. A palisade layer (PAL) of seeds plated with gold were observed using an SEM (Jeol, JSM-5410LV, Tokyo, Japan) at condition of $15 \mathrm{kV}$ [21].

\subsection{Acid Value}

The acid value of kenaf seed was determined according to Korean Food Standards Codex [22]. One gram samples were weighed in $200 \mathrm{~mL}$ Erlenmeyer flask and dissolved in $100 \mathrm{~mL}$ of ethanol:diethyl ether mixture (1:1, v/v) for 1 min and titrated with 2-3 drops of $0.1 \mathrm{~N}$ potassium hydroxide solution, using $1 \%$ phenolphthalein as an indicator. Simultaneously, a blank test (ethanol:diethyl ether mixture $=1: 1, \mathrm{v} / \mathrm{v}$ ) was carried out and then acid value was calculated. Analyses were carried out in triplicate and the acid value was the $\mathrm{mg} \mathrm{KOH}$ used to neutralize $1.0 \mathrm{~g}$ of sample.

\subsection{Evaluation of Fungicide Effect on Surging Seed Germination in Soil}

To evaluate the fungicide effect on surging seed germination in soil, the previous treatment method was modified. A fungicide "Tiram" $(30 \mathrm{~mL} / \mathrm{kg})$ with a brand name Saechong was used. Kenaf seed was coated with Tiram and soaked in Tiram solution according to trial designs. The trial designs consisted of five treatments such as the control (seed unprimed), hydro-priming (HP) for $12 \mathrm{~h}$ (H12), combination of HP for $6 \mathrm{~h}+$ Tiram immersion for $6 \mathrm{~h}$ (H6T6), Tiram immersion for $12 \mathrm{~h}$ (T12), and combination of HP for $12 \mathrm{~h}+$ Tiram coating (H12TC). The treated seeds were planted one at a time in a pot with 105 holes. Germination was scored every day for $7 \mathrm{~d}$. A seed has germinated when the leaves come out. The T50 and MDG were noted to evaluate germination performance. Plant height was measured using ruler and expressed in centimeter at $7 \mathrm{~d}$ after sowing.

\subsection{Field Growth Conditions during the Experimental} Period

The experimental field is situated in Iksancity. During the experimental period, from 1st May 2017 to 15th October 2017, the average minimum temperature in the area was $17.3{ }^{\circ} \mathrm{C}$ and average maximum temperature was $25.3{ }^{\circ} \mathrm{C}$, with a total of $580 \mathrm{~mm}$ rainfall (Table 1). The optimum temperature for kenaf to grow ranges from $20^{\circ} \mathrm{C}$ to $27^{\circ} \mathrm{C}$ [23] and rainfall of 500-600 mm [24]. Thus, the climatic conditions in Iksancity are very suitable to raise kenaf. The primary weeds in the field were tumble pigweed (Amaranthus albus L.), purslane (Portulaca oleracea, Purslane) and removed throughout the growing season by hand weeding.

\subsection{Statistics}

Results were analyzed for analysis of variance 
Table 1 Climatic conditions of field during the experimental period.

\begin{tabular}{|c|c|c|c|c|}
\hline \multirow{2}{*}{ Region } & \multicolumn{3}{|c|}{ Temperature $\left({ }^{\circ} \mathrm{C}\right)$} & \multirow{2}{*}{-Rainfall (mm) } \\
\hline & Av. minimum & Av. maximum & Av. & \\
\hline Iksan & 17.3 & 25.3 & 22.5 & 580 \\
\hline
\end{tabular}

Av.: average.

(ANOVA) using SAS Enterprise Guide 4.2 (Statistical Analysis System, 2009, SAS Institute Inc., Cary, NC, USA). Means were compared at 5\% significance level using Duncan’s multiple comparison.

\section{Results and Discussion}

\subsection{Effect of PEG on Germination Percentage in Laboratory Test}

Germination of Jangdae seed, early maturing variety, was generally poor in the control condition based on kenaf seed maturity compared to the late maturing variety imported from foreign countries such as China (Fig. 1). This indicates the need for kenaf seed to use a priming technique like PEG to hasten germination uniformity and capability. Table 2 illustrates the final germination rate against time. At the first $12 \mathrm{~h}$ of treatment, the maximum germination rate was $83.8 \%$ using $\mathrm{HP}$ as compared to the control's (seed unprimed with HP and PEG) germination percentage of $0 \%$. The highest germination rate was recorded in 10\% PEG between $24 \mathrm{~h}$ and $48 \mathrm{~h}$. At $72 \mathrm{~h}$, the first seedlings to germinate died from fungal infection, resulting to a decrease in germination. It is concluded that $10 \%$ PEG was the critical concentration to surge germination. This method reduced the time required to initiate seed germination. Kim et al. [25] reported that the pasture seed germination increased at 10\%-30\% PEG treatment. These results are attributed to chemical effects of PEG causing the cell wall to lose thus increasing water uptake of cells. The most probable mechanism for PEG enhancement of germination is the intensification of mass transfer and easier access of water to the interior of the cell wall structure. Results after $72 \mathrm{~h}$ were obtained from seedlings that had survived. Significant difference in survival rate of the seedlings was recorded among treatments. The $90 \%$ survival rate of at 20\% and 25\% PEG treatment were significantly greater than that of the other treatments. Ismail et al. [26] stated that a higher germination percentage was obtained with PEG treatment compared to the control. PEG was the preferred osmoticum because it is inert and the embryo cannot take up its large molecular size [7]. PEG's composition hinders too much water absorption by the seed. Excessive water absorption by the seeds hampers seed germination. Also, Davision and Bray [27] suggested that PEG treatment induced various proteins synthesis related with germination. The earlier germinated seedlings after priming treatment such as HP and 10\% PEG died first. Previous studies on cotton and kenaf showed a strong association between rapid germination and seed coat susceptibility to mold growth, seed rot and diseased seedling roots $[16,28]$.

Germination synchronization, shoot length and leaf unfolding of primed seed were greater than those of the control. Also, main root or hair root appeared faster in the treated seeds and grew abundantly compared to the control (Fig. 1). Enhanced effect, which hastens germination rate and growth progress, was greatest at HP and 10\% PEG compared to the control (Fig. 1).

\subsection{Effects of PEG on Surging both T50 and MDG in Laboratory Test}

Results showed that the T50 of the control was 22 times, while at HP and 10\% PEG treatment, nine times was sufficient to reach T50 which is 2-3 times lower than that of the control (Table 3). The T50 of the other PEG treatments was also lower than that of the 
Table 2 Response of kenaf seed germination at various polyethylene glycol (PEG) concentrations and different time immersions in $\mathrm{H}_{2} \mathrm{O}$ solution.

\begin{tabular}{lllllllll}
\hline \multirow{2}{*}{ Hours } & \multicolumn{7}{c}{ PEG (\%) } \\
\cline { 2 - 9 } & Control & HP & 10 & 20 & 25 & 30 & 35 & 40 \\
\hline 12 & 0d & $83.8 \mathrm{a}$ & $78.8 \mathrm{ab}$ & $65.0 \mathrm{~b}$ & $21.3 \mathrm{c}$ & $0 \mathrm{~d}$ & $0 \mathrm{~d}$ & $0 \mathrm{~d}$ \\
24 & $48.8 \mathrm{~b}$ & $90.0 \mathrm{a}$ & $96.3 \mathrm{a}$ & $93.8 \mathrm{a}$ & $83.8 \mathrm{a}$ & $56.3 \mathrm{~b}$ & $57.5 \mathrm{~b}$ & $57.5 \mathrm{~b}$ \\
48 & $85.0 \mathrm{~b}$ & $91.3 \mathrm{ab}$ & $96.3 \mathrm{a}$ & $95.0 \mathrm{a}$ & $91.3 \mathrm{ab}$ & $83.8 \mathrm{~b}$ & $90.0 \mathrm{ab}$ & $91.3 \mathrm{ab}$ \\
72 & $72.5 \mathrm{c}$ & $77.5 \mathrm{bc}$ & $86.3 \mathrm{ab}$ & $90.0 \mathrm{a}$ & $90.0 \mathrm{a}$ & $80.0 \mathrm{abc}$ & $88.8 \mathrm{a}$ & $83.8 \mathrm{ab}$ \\
\hline
\end{tabular}

The different letters for each row show significant difference $(p<0.05)$ using Duncan's multiple range test.

Control: seed unprimed with hydro-priming (HP) and PEG; HP: seed primed with hydro-priming; $72 \mathrm{~h}$ means a survival rate of seedlings.

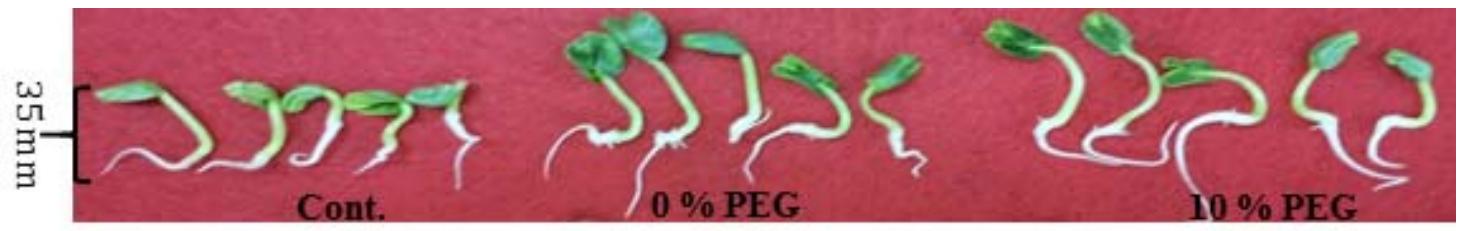

Fig. 1 Comparison of seedlings at various polyethylene glycol (PEG) concentrations after 3 d of germination in $\mathrm{H}_{2} \mathrm{O}$ condition.

Cont.: unprimed seeds; 0\% PEG: hydro-priming (HP).

control. MDG decreased from $1.43 \mathrm{~d}$ which is the maximum for the control and $0.55 \mathrm{~d}$ being the minimum for HP (Table 3). These data indicate that the T50 and MDG were significantly affected by the PEG priming during germination. Previous study demonstrated that the increase in the germination rate and MDG of primed barley seeds may be due to the initial metabolic events in primed seeds [29]. Li et al. [30] reported that the seed primed with PEG showed a fast MDG, resulting in improving the germination rate rather than an increase in the germination percentage. It appeared that PEG treatment might induce various proteins synthesis related with germination [27].

\subsection{Effect of PEG on Germination Percentage in Field Test}

The results of the germination percentage in the field after PEG treatment is presented in Table 4. After sowing kenaf seeds, it rained on the 10th (40 $\mathrm{mm})$ and the 21st $(15 \mathrm{~mm})$ days. The germination percentage of HP on the 6th day was significantly higher than the others (Table 4). After raining of 40 $\mathrm{mm}$ on the 10th day, the germination percentage of the control on the 11th day exceeded that of other treatments. Thereafter, the control's (Jangdae seed) germination in the field was increased sharply and reached a maximum of $53.2 \%$ on the 21 st day when it rained for $15 \mathrm{~mm}$ a day. After the 21st day, there was no significant difference in the germination of all the experimental plots (Table 4). Daniel et al. [5] demonstrated that HP of kenaf seeds for $24 \mathrm{~h}$ enhanced seed germination and vigor. However, it has been observed that there was a significant difference in germination among varieties after priming. So, the variety difference between the result and previous study [5] indicated different outcomes.

\subsection{Effect of PEG on Biomass Yield in Field Test}

Results showed that biomass yields of different priming treatment plots (Hydro and PEG) were lower than that of the control (Jangdae) in $150 \mathrm{~d}$ (Fig. 2). No significant difference was also observed among the priming treatment plots. The biomass yield depends on the germination percentage (Table 4). Hence, it is very important to apply an optimum plant density so as to obtain the highest yield. In this study, kenaf was planted with sowing density of 25,000 plants/10a. Previous studies reported that the best planting density was 40,000 plants/10a [31]. This difference is attributed to the cultivar and climatic condition such as 
Table 3 T50 and MDG of kenaf seed at various PEG concentrations in $48 \mathrm{~h}$.

\begin{tabular}{llll}
\hline PEG (\%) & GP & T50 (times) & MDG \\
\hline Control & $85.0 \mathrm{~b}$ & 22 & 1.43 \\
HP & $91.3 \mathrm{ab}$ & 9 & 0.55 \\
10 & $96.3 \mathrm{a}$ & 9 & 0.59 \\
20 & $95.0 \mathrm{a}$ & 10 & 0.67 \\
25 & $91.3 \mathrm{ab}$ & 14 & 0.97 \\
30 & $83.8 \mathrm{~b}$ & 21 & 1.33 \\
35 & $90.0 \mathrm{ab}$ & 21 & 1.36 \\
40 & $91.3 \mathrm{ab}$ & 21 & 1.37 \\
\hline
\end{tabular}

The different letters for each column show significant difference $(p<0.05)$ using Duncan’s multiple range test.

GP: germination percentage in $48 \mathrm{~h}$; T50: times to reach 50\% of the final germination rate; MDG: mean no. of days to germination; Control: seed unprimed with HP and PEG; HP: seed primed with hydro-priming.

Table 4 Germination rate of kenaf seed at various PEG concentrations on the 6th, 11th, 14th and 21st days.

\begin{tabular}{lllll}
\hline \multirow{2}{*}{ PEG } & \multicolumn{3}{c}{ Germination percentage (\%) } \\
\cline { 2 - 4 } & 6th day & 11th day & 14th day & 21st day \\
\hline Control & $0.3 \mathrm{~b}$ & $14.1 \mathrm{a}$ & $50.5 \mathrm{a}$ & $53.2 \mathrm{a}$ \\
$0(\mathrm{HP})$ & $3.0 \mathrm{a}$ & $9.4 \mathrm{~b}$ & $25.3 \mathrm{~b}$ & $21.5 \mathrm{~b}$ \\
10 & $0.0 \mathrm{~b}$ & $8.8 \mathrm{~b}$ & $24.2 \mathrm{~b}$ & $23.6 \mathrm{~b}$ \\
20 & $0.3 \mathrm{~b}$ & $8.4 \mathrm{~b}$ & $25.9 \mathrm{~b}$ & $26.3 \mathrm{~b}$ \\
25 & $0.3 \mathrm{~b}$ & $3.7 \mathrm{~b}$ & $11.4 \mathrm{~b}$ & $14.5 \mathrm{~b}$ \\
30 & $0.3 \mathrm{~b}$ & $5.4 \mathrm{~b}$ & $13.8 \mathrm{~b}$ & $13.8 \mathrm{~b}$ \\
35 & $0.7 \mathrm{~b}$ & $7.4 \mathrm{~b}$ & $24.9 \mathrm{~b}$ & $27.3 \mathrm{~b}$ \\
40 & $0.3 \mathrm{~b}$ & $5.4 \mathrm{~b}$ & $26.3 \mathrm{~b}$ & $26.9 \mathrm{~b}$ \\
\hline
\end{tabular}

The different letters for each column show significant difference $(p<0.05)$ using Duncan’s multiple range test. Control: Jangdae seed unprimed with HP and PEG; HP: seed primed with hydro-priming.

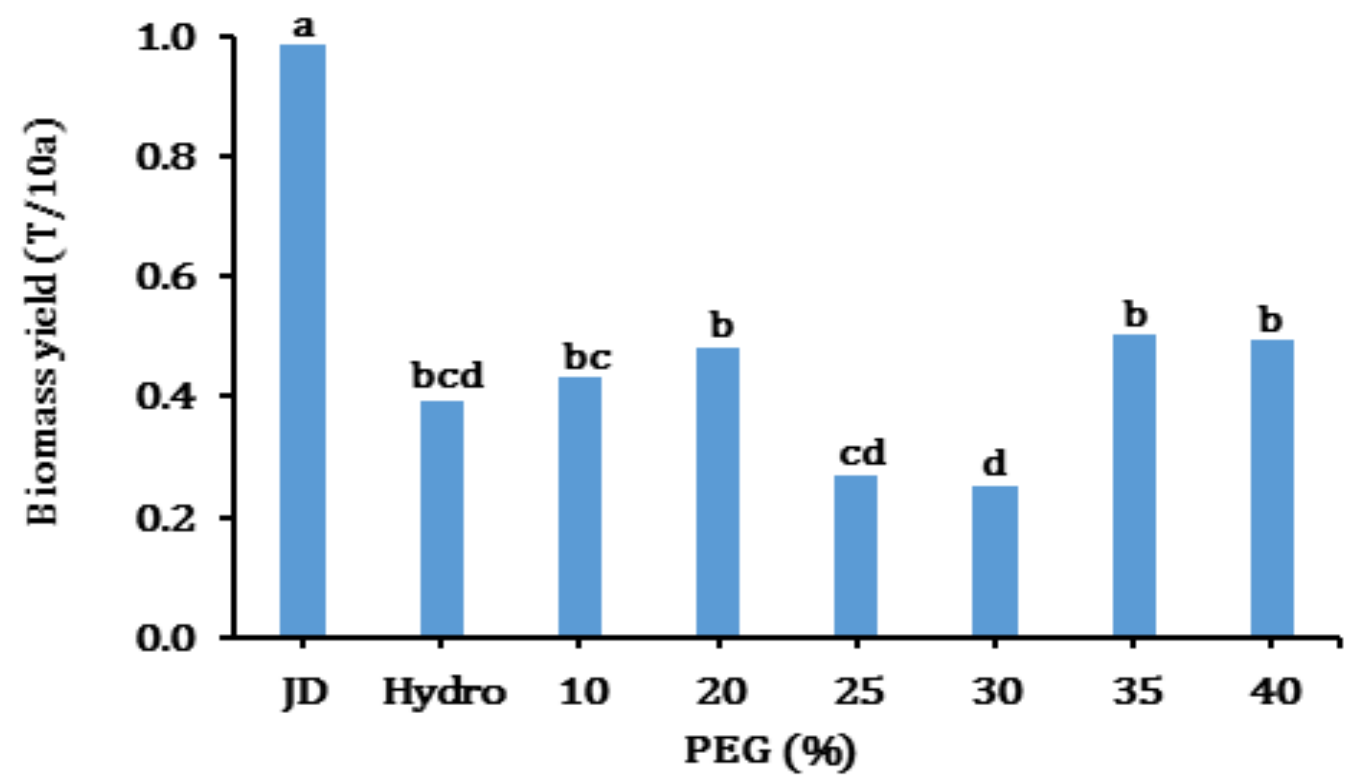

Fig. 2 Yield of kenaf at various PEG concentrations at $150 \mathrm{~d}$ in the field.

The different letters for each bar graph show significant difference using Duncan's multiple range test.

JD: control (unprimed seeds); Hydro: HP (seed primed with hydro-priming). 
rainfall and temperature.

\subsection{Identification of Cause of Low Priming Effect in Field Test}

Tables 2 and 4 showed that it is possible to determine the priming effect to increase germination percentage in growth chamber condition, but not in soil condition. Thus, the cause of low priming effect in soil was also identified. In the SEM image of tissue before and after priming treatment, there was a significant difference in the PAL (Fig. 3). The PAL (white parenthesis) after priming treatment was more

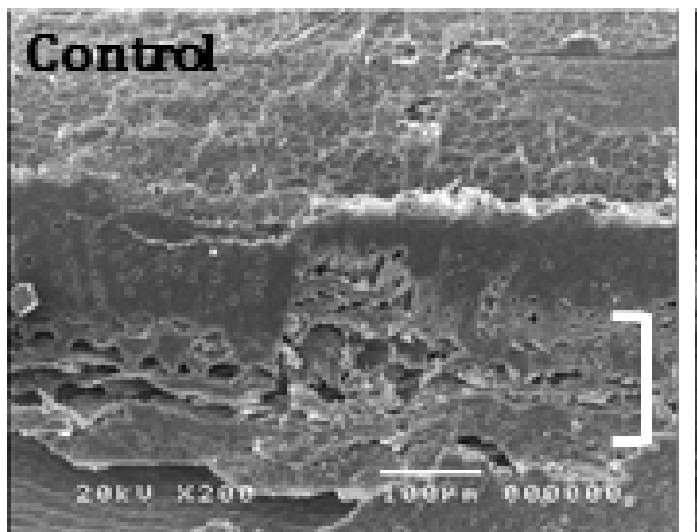

Fig. 3 Scanning electron microscope (SEM) image of the cross section of kenaf seed coat after PEG priming treatment for 24 h.

$\mathrm{PAL}=$ palisade layer; control $=$ unprimed seed.

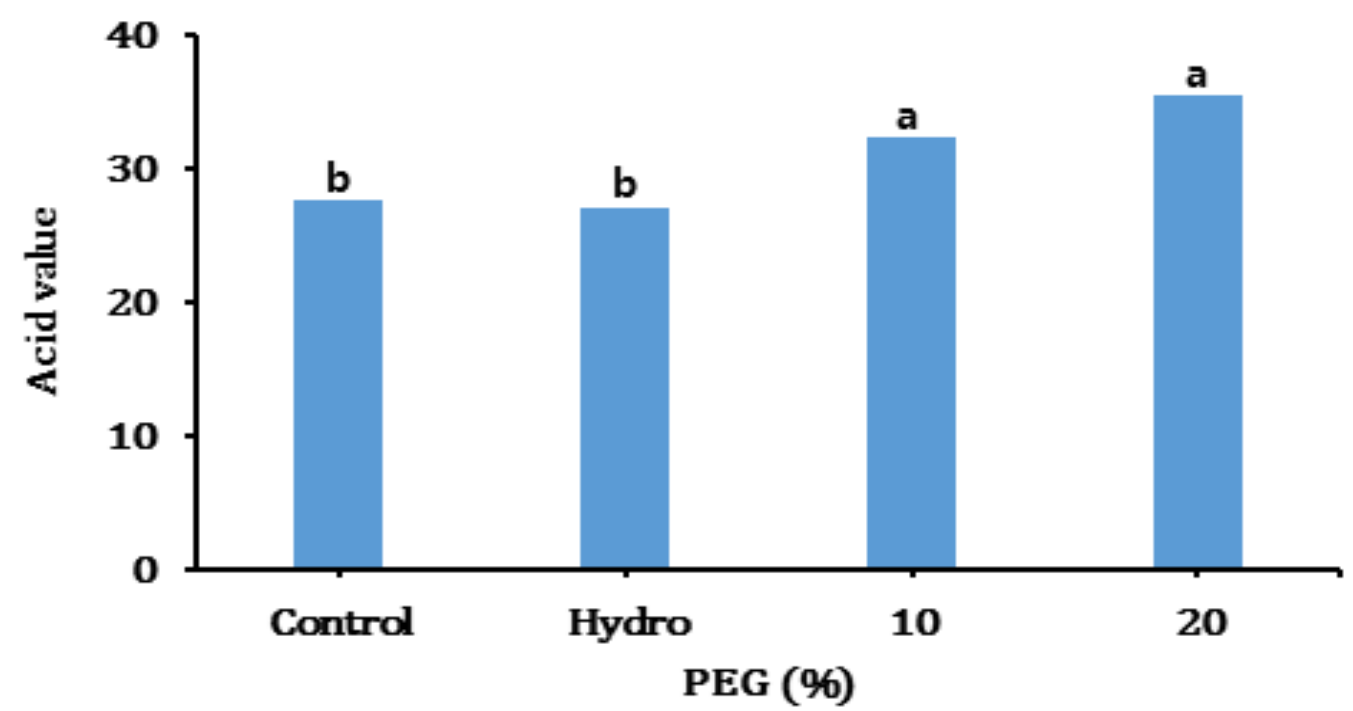

Fig. 4 Acid value difference of kenaf seeds after $24 \mathrm{~h}$ at various PEG concentrations.

The different letters for each bar graph show significant difference $(p<0.05)$ using Duncan’s multiple range test.

Control: seed unprimed with HP and PEG; Hydro: HP (seed primed with hydro-priming). 
[33, 34]. Thus, findings showed that priming treatment over 20\% PEG to kenaf seed is not suitable for improving the germination percentage. The study showed that tissue disintegration and fatty acid's oxidation of kenaf seed after priming had significantly negative effects on germination in soil.

\subsection{Effects of Fungicide Treatment on Kenaf Seed} Germination in Soil Test

To overcome the problem of priming treatment on surging seed germination, a fungicide called Tiram was used after priming. The single treatment of HP and combination of HP and Tiram had a significant effect on decreasing T50 (Fig. 5). Among the treatments, the H6T6 was the highest (Fig. 5). With respect to MDG, the $\mathrm{HP}$ and combination of $\mathrm{HP}$ and Tiram treatment germinated at a significantly faster rate than the control. The H6T6 showed the fastest level (Fig. 6). In the final germination percentage, single treatment of HP and combination of HP and
Tiram had an increasing effect compared to the control (Fig. 7). The H12TC treatment has the highest germination percentage which is $42.44 \%$ as compared to the others which ranged from $25.5 \%$ to $36.2 \%$ (Fig. 7). In plant height evaluation, all treatments resulted higher than the control (Fig. 8). Based on the final germinate on percentage, it appeared that there is a close connection between Tiram treatment and improvement of germination percentage. According to Ref. [16], the stand establishment of kenaf after fungicide treatment soared. It was concluded that fungicide treatment could help kenaf seed improve germination percentage and stand establishment by protecting the seeds from seed- and soil-borne pathogens.

In conclusion, the study performed with kenaf suggested that the seeds can be applied with a technique called H12TC, which is a combination of HP and Tiram-coating, to boost germination. Finally, the technique called H12TC is recommended to improve the economic yield of kenaf.

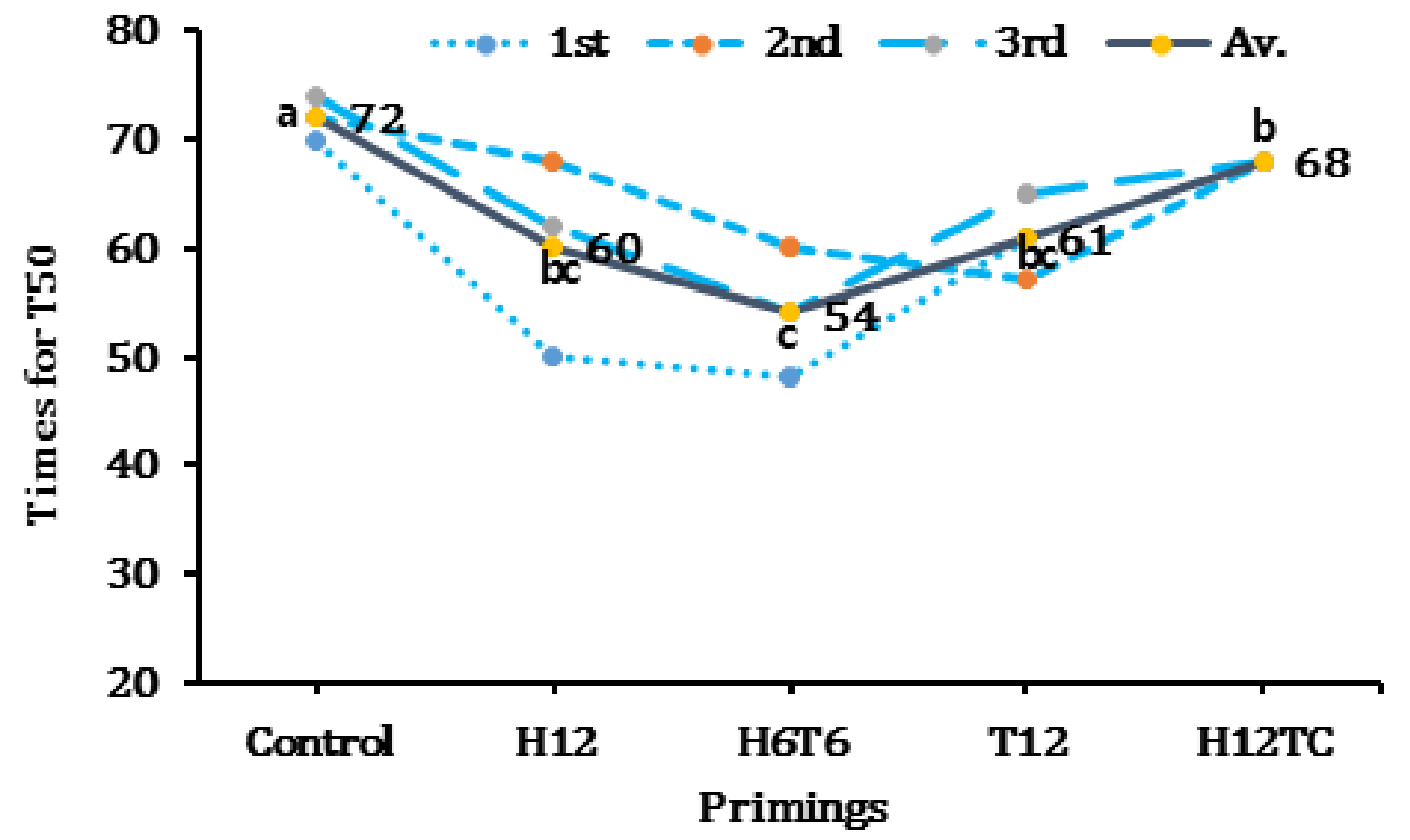

Fig. 5 T50 difference of kenaf seeds after $\mathbf{7 2} \mathbf{h}$ at various treatments.

The different letters show significant difference $(p<0.05)$ using Duncan's multiple range test.

Control: seed unprimed with HP and PEG; H12: HP treatment for 12 h; H6T6: HP treatment for 6 h, followed by treatment in Tiram solution for 6 h; T12: treatment in Tiram solution for 12 h; H12TC: HP treatment for 12 h, followed by coating with Tiram suspension. The solid line indicates the average from 1st to 3rd. 
Seed Germination

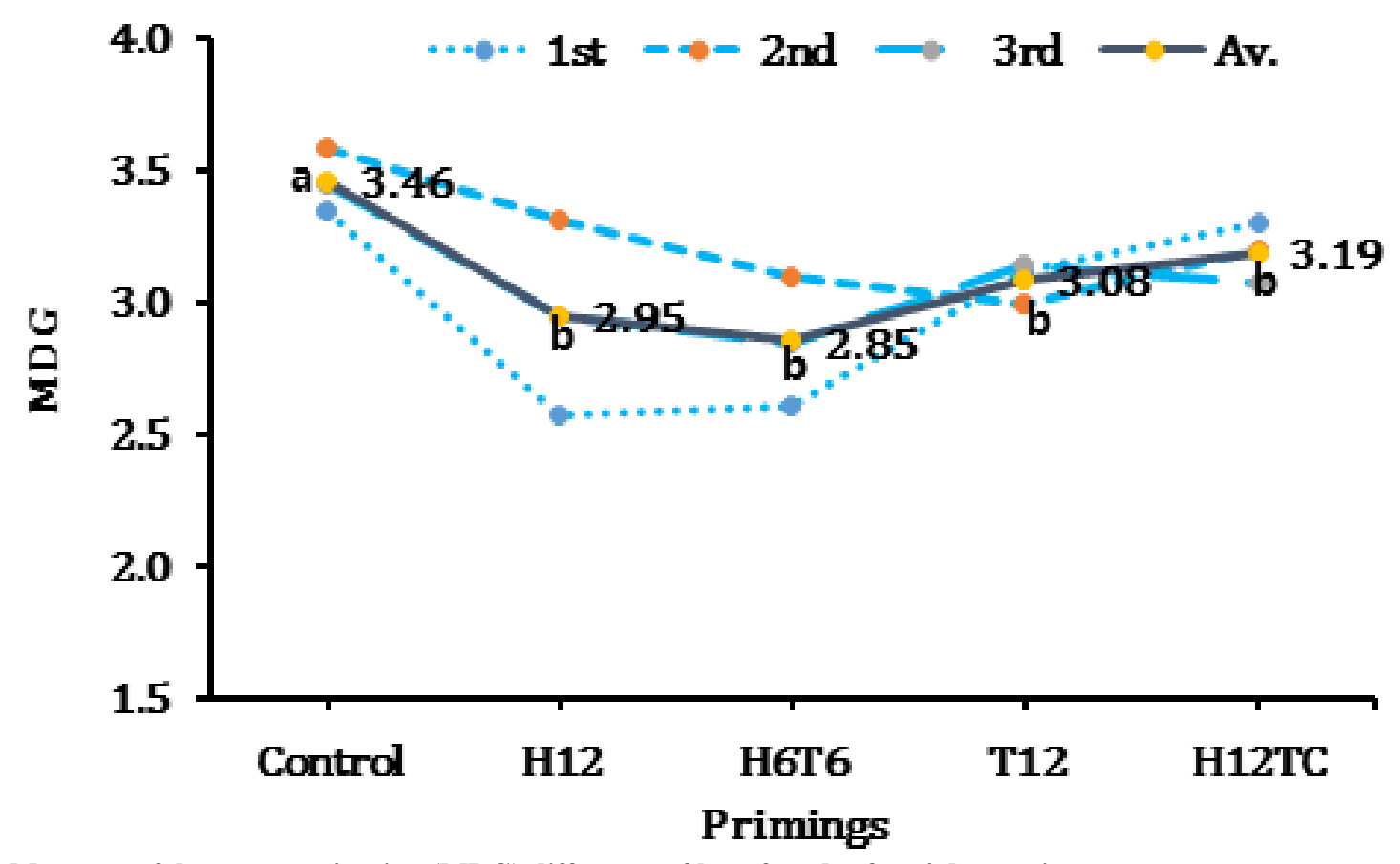

Fig. 6 Mean no. of days to germination (MDG) difference of kenaf seeds after $4 \mathrm{~d}$ at various treatments. The different letters show significant difference $(p<0.05)$ using Duncan's multiple range test.

Control: seed unprimed with HP and PEG; H12: HP treatment for 12 h; H6T6: HP treatment for 6 h, followed by treatment in Tiram solution for 6 h; T12: treatment in Tiram solution for 12 h; H12TC: HP treatment for 12 h, followed by coating with Tiram suspension. The solid line indicates the average from 1st to 3rd.

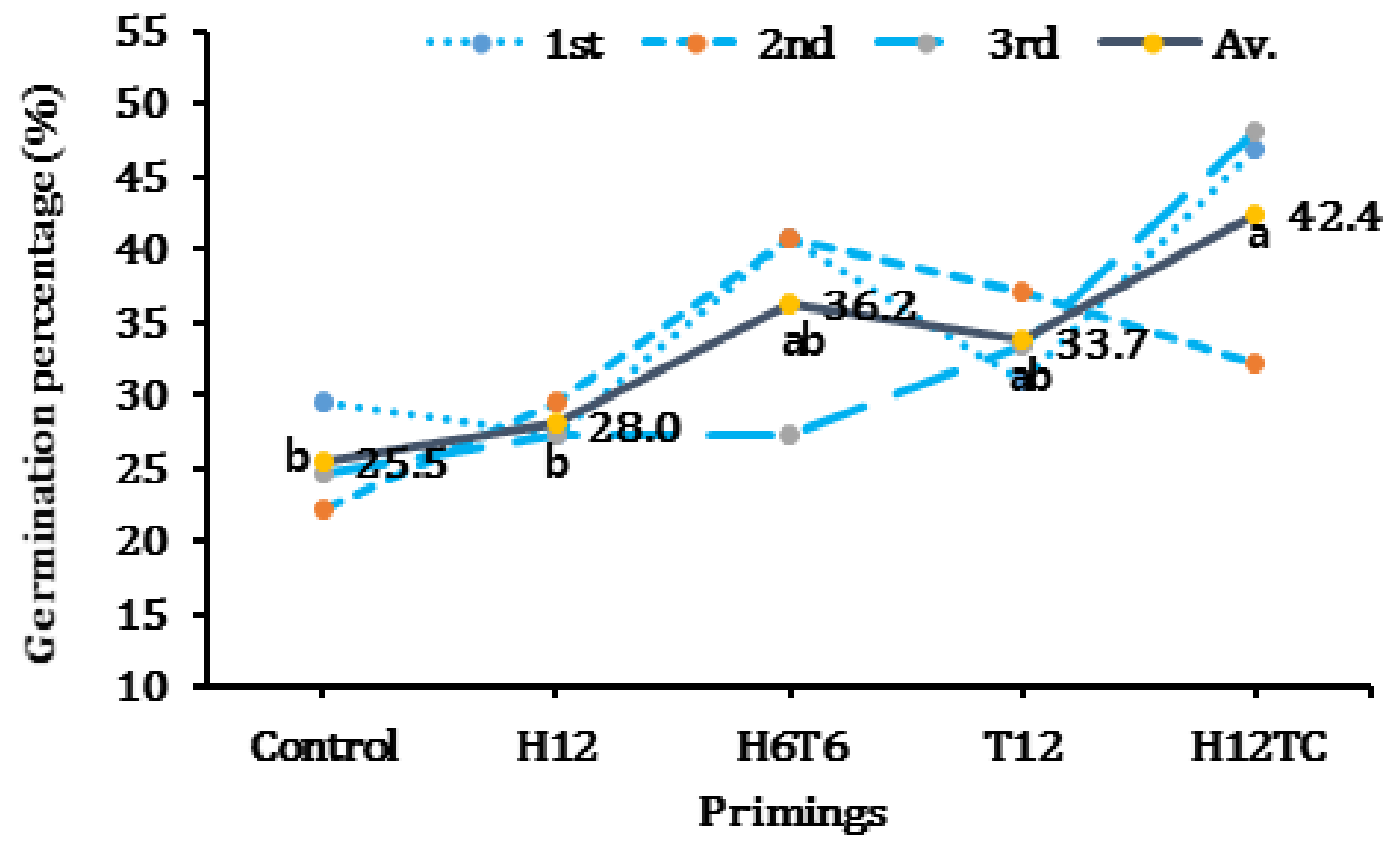

Fig. 7 Germination percentage of kenaf seeds after $7 \mathbf{d}$ at various treatments.

The different letters show significant difference $(p<0.05)$ using Duncan's multiple range test.

Control: seed unprimed with HP and PEG; H12: HP treatment for 12 h; H6T6: HP treatment for 6 h, followed by treatment in Tiram solution for 6 h; T12: treatment in Tiram solution for 12 h; H12TC: HP treatment for 12 h, followed by coating with Tiram suspension. The solid line indicates the average from 1 st to 3 rd. 


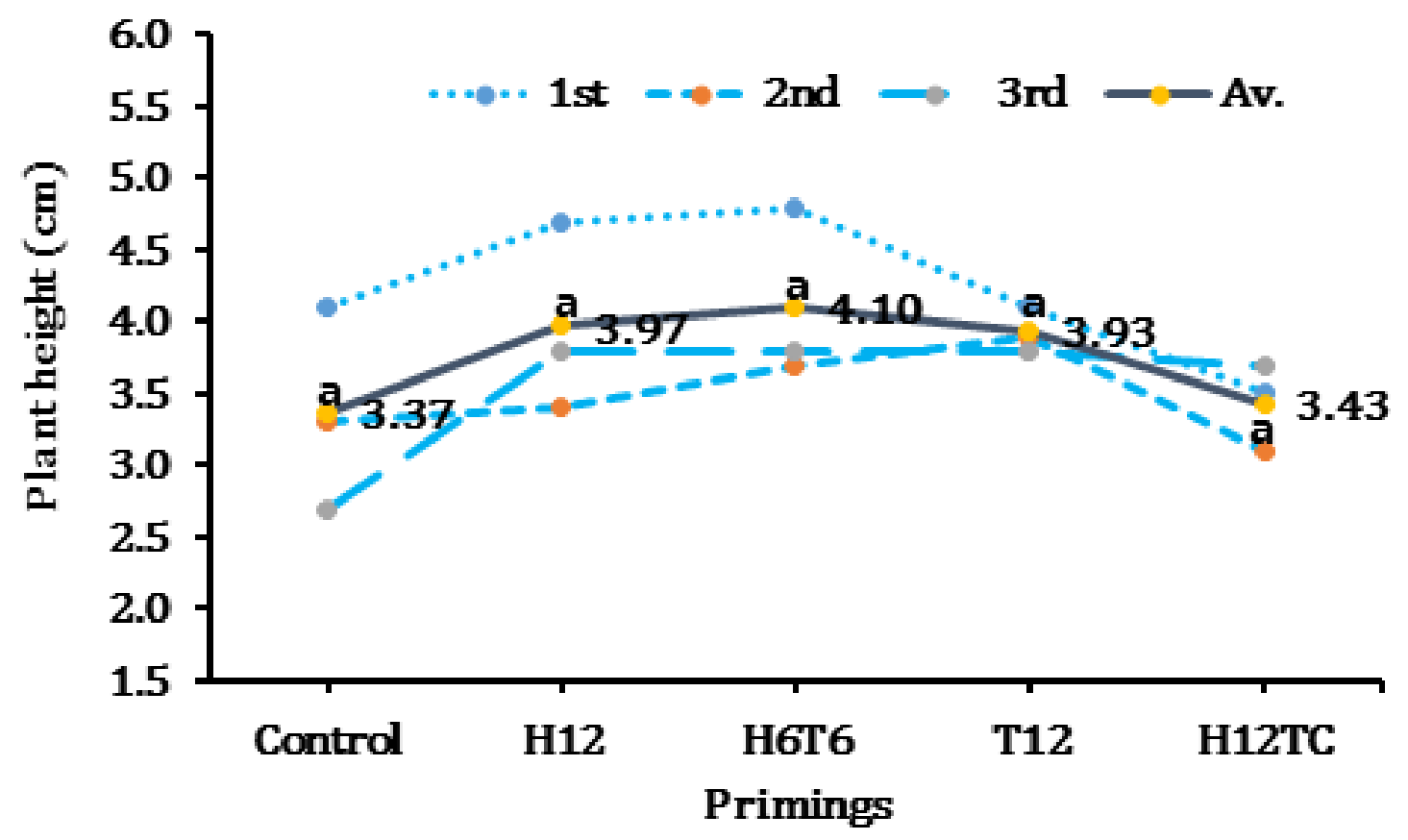

Fig. 8 Plant height of kenaf seedlings after $7 \mathbf{d}$ at various treatments.

The different letters show significant difference $(p<0.05)$ using Duncan's multiple range test.

Control: seed unprimed with HP and PEG; H12: HP treatment for 12 h; H6T6: HP treatment for 6 h, followed by treatment in Tiram solution for 6 h; T12: treatment in Tiram solution for 12 h; H12TC: HP treatment for 12 h, followed by coating with Tiram suspension. The solid line indicates the average from 1 st to $3 r d$.

\section{Conclusions}

The present study showed that a germination, T50, MDG, shoot length and leaf unfolding of kenaf seed were significantly influenced by priming technique like HP and PEG. Results represented that the optimum priming condition to hasten germination uniformity and capability of kenaf seed is 10\% PEG in laboratory test. However, the germination percentage in the field after PEG treatment was different compared to the results of previous treatment. Hence, the authors analyzed SEM image and acid level of kenaf seeds to deepen its understanding. Tissue disintegration and fatty acid's oxidation of kenaf seed after priming had significantly negative effects on germination in soil. This is the first report to identify the cause of low priming effect in field test. To overcome the problem of priming treatment on surging seed germination in field test, a fungicide called Tiram was used after priming. Of four treatments, H12TC (a combination of HP and
Tiram-coating) can be used as a good priming technology to help kenaf seed improve germination percentage and stand establishment by protecting the seeds from seed- and soil-borne pathogens.

\section{Acknowledgments}

This work was supported in part with grants from the Korea South-East Power Company.

\section{References}

[1] Yazan, L. S., Foo, J. B., Ghafar, S. A. A., Chan, K. W., Tahir, P. M., and Ismail, M. 2011. "Effect of Kenaf Seed Oil from Different Ways of Extraction towards Ovarian Cancer Cells.” Food Bioprod. Process. 89 (4): 328-32.

[2] Danalatos, N. G., and Archontoulis, S. V. 2010. "Growth and Biomass Productivity of Kenaf (Hibiscus cannabinus L.) under Different Agricultural Inputs and Management Practices in Central Greece.” Ind. Crop Prod. 32: 231-40.

[3] Columbus, E. P., and Fuller, M. J. 1999. "Factors Affecting Kenaf Fiber and Core Separation.” In Kenaf Properties, Processing and Products. Oktibbeha, Mississippi: Mississippi State University Press.

[4] Carberry, P. S., and Abrecht, D. G. 1990. "Germination 
and Elongation of the Hypocotyls and Radicle of Kenaf (Hibiscus cannabinus L.) in Response to Temperature.” Field Crops Research 24 (4): 227-40.

[5] Daniel, I. O., Adeniyan, O. N., Adetumbi, J. A., Okelana, M. A., Olakojo, S. A., Ajala, M. O., Aluko, O. A., and Adekoya, M. A. 2012. "Hydro-Priming Improved Germination and Vigour of Kenaf (Hibiscus cannabinus L.) Seeds.” Food Agriculture and Environment 10 (2): 760-3.

[6] Bennett, M. A. 1998. "The Use of Biologicals to Enhance Vegetable Seed Quality.” Seed Technol. 20: 198-208.

[7] McDonald, M. B. 2000. "Seed Priming." In Seed Technology and Its Biological Basis. LLC. Boca Raton, Florida: CRC Press.

[8] Gurusinghe, S. H., Cheng, Z., and Bradford, K. J. 1999. "Cell Cycle Activity during Seed Priming Is not Essential for Germination Advancement in Tomato.” J. Exp. Bot. 50: 101-6.

[9] Janmohammadi, M., Dezfuli, P. M., and Sharifzadeh, F. 2008. "Seed Invigoration Techniques to Improve Germination and Early Growth of Inbred Line of Maize under Salinity and Drought Stress.” General and Applied Plant Physiology 4: 215-26.

[10] Jahangir, M. M., Amjad, M., Afzal, I., Iqbal, Q., and Nawaz, A. 2009. "Lettuce Achene Invigoration through Osmopriming at Supraoptimal Temperature.” Pakistan Journal of Agricultural Sciences 46: 1-6.

[11] Finnerty, T. L., Zajicek, J. M., and Hussey, M. A. 1992. "Use of Seed Priming to Bypass Stratification Requirements of Three Aquilegia Species.” HortScience 27: 310-3.

[12] Nayyar, H., and Malik, C. P. 1993. "Alleviation of Drought Stress in Pigeonpea with Mixtalol Seed Priming." Agric. Sci. 13: 27-30.

[13] Rao, S. C., and Phillips, W. A. 1993. "Effect of Seed Priming and Soil Residueon Seedling Emergence and Forage Production of Brassicas.” Journal of Sustainable Agriculture 3: 89-98.

[14] Duman, I., and Esiyok, D. 1998. "Effect of Pre-sowing PEG and $\mathrm{KH}_{2} \mathrm{PO}_{4}$ Treatment on Germination Emergence and Yield of Carrot.” Turk. J. Agric. For. 22: 445-9.

[15] Bradford, K. J. 1986. "Manipulation of Seed Water Relations via Osmotic Priming to Improve Germination under Stress Conditions.” HortScience 21: 1105-12.

[16] Cook, C. G., Hickmanb, M. V., Webber, C. L., Sij, J. W., and Scotte, A. W. 1992. "Fungicide Treatment Effects on Kenaf Seed Germination and Stand Establishment.” Industrial Crops and Products 1: 41-5.

[17] Presley, J. T., Summers, T. E., and Crandall, B. S. 1964. "The Anthracnose Disease of Kenaf and Its Control.” In Proceedings of the 2nd International Kenaf Conference, 19-33.
[18] Whiteley, E. L. 1968. "Seed Treatment and Planting Equipment." In Proceedings of the 1st Conference on Kenaf for Pulp, 32-3.

[19] White, G. A., Adamson, W. C., Whiteley, E. L., and Massey, J. H. 1971. "Emergence of Kenaf Seedlings as Affected by Seed Fungicides.” Agron. J. 63: 484-6.

[20] Bañuelos, G. S., Bryla, D. R., and Cook, C. G. 2002. "Vegetative Production of Kenaf and Canola under Irrigation in Central California.” Industrial Crops and Products 15 (3): 237-45.

[21] Bednorz, L., and Czarna, A. 2008. "SEM and Stereoscope Microscope Observations on the Seeds of Some Ornithogalum (Hyacinthaceae) Species.” Biologia. 63 (5): 642-6.

[22] Korea Food and Drug Administration. 2016. Korea Food Code, 2016: No. 5 Standards and Specifications of Each Food. Korea Food and Drug Administration, Korea, 46-7.

[23] Monti, A., and Zatta, A. 2009. "From Growing Kenaf to Its Industrial Use.” In Proceedings of the 1st Workshop on EU Project Crops 2 Industry, 4.

[24] Eruola, A., Awomeso, J., Kassim, G. U. H., and Makinde, A. 2014. "An Assessment of Rain Water Supply for Kenaf-Maize Intercrop.” Irrigation \& Drainage Systems Engineering 3 (3): 1-7.

[25] Kim, J. D., Kwon, C. H., Chae, S. H., Hur, S. N., and Kim, J. G. 2006. "Effect of Priming Materials and Its Concentrations on the Germination of Pasture Seed.” J. Korean Grassl. Sci. 26 (4): 277-84.

[26] Ismail, A. I., El-Araby, M. M., Hegazi, A. Z. A., and Moustafa, S. M. A. 2005. "Optimization of Priming Benefits in Tomato (Lycopersicon esculentum M.) and Changes in Some Osmolytes the Hydration Phase.” Asian Journal of Plant Sciences 4: 691-701.

[27] Davision, P. A., and Bray, C. M. 1991. "Protein Synthesis during Osmopriming of Leek (Allium porrum L.) Seeds.” Seed Science Research 1: 29-35.

[28] Bird, L. S. 1982. "The MAR (Multi-Adversity Resistance) System for Genetic Improvement of Cotton.” Plant Dis. 66: 172-6.

[29] Yaldagard, M., Mortazavi, S. A., and Tabatabaie, F. 2008. "Influence of Ultrasonic Stimulation on the Germination of Barley Seed and Its Alpha-Amylase Activity.” African Journal of Biotechnology 7 (14): 2465-71.

[30] Li, X. R., Yu, C. Y., and Kim, I. S. 1999. "Effects of Pre-sowing Seed Treatments on Germination and Seedling Emergence of Carrot.” J. Agr. Sci. 10: 10-7.

[31] Manzanares, M., Tenorio, J. L., Molina, J. R., and Ayerbe, L. 1991. "Preliminary Estimation of Kenaf Crop Yield in Spain." In Proceedings of the 5th European Conference on Biomass for Energy and Industry, 22-6.

[32] Roberts, E. H. 1986. "Quantifying Seed Deterioration.” In Physiology of Seed Deterioration. Madison, Wisconsin: 


\section{Seed Germination}

Crop Science Society of America.

[33] Lee, I. S., Song, Y. E., Han, H. A., Song, E. J., Choi, S. R., and Lee, K. K. 2016. "Physicochemical Properties of Oat (Avena sativa L.) Flour according to Various Roasting Conditions." The Korean Journal of Crop
Science 62 (1): 32-9.

[34] Serjouie, A., Tan, C. P., Mirhosseini, H., and Man, Y. B. C. 2010. "Effect of Vegetable Based Oil Blends on Physicochemical Properties of Oils during Deep-Fat Frying.” American J. of Food Technology 5 (5): 310-23. 